\title{
APC2 is critical for ovarian WNT signalling control, fertility and tumour suppression
}

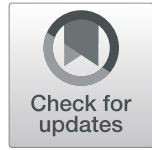

Noha-Ehssan Mohamed ${ }^{1,2,3}$, Trevor Hay ${ }^{1}$, Karen R. Reed ${ }^{1}$, Matthew J. Smalley ${ }^{1 * \dagger} \mathbb{D}$ and Alan R. Clarke ${ }^{1{ }^{\wedge}}$

\begin{abstract}
Background: Canonical WNT signalling plays a critical role in the regulation of ovarian development; mis-regulation of this key pathway in the adult ovary is associated with subfertility and tumourigenesis. The roles of Adenomatous polyposis coli 2 (APC2), a little-studied WNT signalling pathway regulator, in ovarian homeostasis, fertility and tumourigenesis have not previously been explored. Here, we demonstrate essential roles of APC2 in regulating ovarian WNT signalling and ovarian homeostasis.

Methods: A detailed analysis of ovarian histology, gene expression, ovulation and hormone levels was carried out in 10 week old and in aged constitutive APC2-knockout $\left(\mathrm{ApC}^{-1-}\right)$ mice (mixed background). Statistical significance for qRT-PCR data was determined from 95\% confidence intervals. Significance testing was performed using 2-tailed Student's t-test, when 2 experimental cohorts were compared. When more were compared, ANOVA test was used, followed by a post-hoc test (LSD or Games-Howell). P-values of $<0.05$ were considered statistically significant.

Results: APC2-deficiency resulted in activation of ovarian WNT signalling and sub-fertility driven by intra-ovarian defects. Follicular growth was perturbed, resulting in a reduced rate of ovulation and corpora lutea formation, which could not be rescued by administration of gonadotrophins. Defects in steroidogenesis and follicular vascularity contributed to the subfertility phenotype. Tumour incidence was assessed in aged APC2-deficient mice, which also carried a hypomorphic Apc allele. APC2-deficiency in these mice resulted in predisposition to granulosa cell tumour (GCT) formation, accompanied by acute tumour-associated WNT-signalling activation and a histologic pattern and molecular signature seen in human adult GCTs.

Conclusions: Our work adds APC2 to the growing list of WNT-signalling members that regulate ovarian homeostasis, fertility and suppress GCT formation. Importantly, given that the APC2-deficient mouse develops tumours that recapitulate the molecular signature and histological features of human adult GCTs, this mouse has excellent potential as a pre-clinical model to study ovarian subfertility and transitioning to GCT, tumour biology and for therapeutic testing.
\end{abstract}

Keywords: APC2, APC hypomorph, WNT signalling, Ovarian fertility, Ovarian cancer, Granulosa cell tumour

\section{Background}

The canonical WNT signalling pathway is central to numerous biological processes and diseases [1]. Within the ovary, the pathway has been shown to be essential for female sex differentiation during embryogenesis [2-9], however, in the adult ovary its role is less well defined. Conditional deletion of $\beta$-catenin within murine granulosa cells of antral follicles did not affect folliculogenesis

\footnotetext{
* Correspondence: SmalleyMJ@Cardiff.ac.uk

Deceased

${ }^{1}$ European Cancer Stem Cell Research Institute, Cardiff University School of Biosciences, Hadyn Ellis Building, Maindy, Road, Cardiff CF24 4HQ, UK
} Full list of author information is available at the end of the article or ovulation $[10,11]$, but its removal within oviducts and uteri led to abnormalities therein, with lack of implantation sites rendering mice infertile as a result [11]. Conditional deletion of Wnt4 in ovarian granulosa cells or germline deletion of $\mathrm{Fzd} 4$ in mice caused sub-fertility or complete infertility respectively [12, 13], but WNT signalling activity was not measured and it is unclear whether the reported phenotypes were caused by impaired ovarian canonical WNT signalling or by other mechanisms, potentially including non-canonical pathways. In mice with germline deletion of the WNT signalling agonist $F z d 1$,

(c) The Author(s). 2019 Open Access This article is distributed under the terms of the Creative Commons Attribution 4.0 International License (http://creativecommons.org/licenses/by/4.0/), which permits unrestricted use, distribution, and 
$17.6 \%$ of female mice were infertile and characterized by early follicle depletion, but with no concomitant change in total activated $\beta$-catenin levels [14]. Overactivation of canonical WNT signalling also has deleterious effects on ovarian homeostasis. Ovarian amplification of Rspo1 [15], deletion of Wnt5a (antagonist of canonical WNT signalling) [16] or expression of dominant stable $\beta$-catenin $[10,17]$ all resulted in up-regulated ovarian WNT signalling and ovarian subfertility caused by disruption of follicle growth $[16,17]$, ovulation and luteinisation $[10,15]$. Taken together, these findings indicate the importance of tight regulation of canonical WNT signalling in growing follicles.

Human ovarian tumours are classified into epithelial ovarian cancers (90\%), sex cord-stromal tumours (7\%) and germ cell tumours (3\%). Granulosa cell tumours (GCTs), which originate from granulosa cells of ovarian follicles, account for more than half of sex cord-stromal tumours [18]. WNT signalling mis-regulation has been implicated in adult GCT formation, as several studies have demonstrated increased $\beta$-catenin protein levels therein, with nuclear localisation in some cases $[17,19$, 20]. A recent molecular study of GCTs showed epigenetic silencing of $D K K 3$, the gene coding for the WNTsignalling antagonist Dickkopf, implying a need for WNT signalling activation in GCT development $(25,26)$ . Furthermore, GEMMs in which WNT signalling was activated via the introduction of a gain-of-function mutation of R-spondin1 [15], or a degradation-resistant $\beta$ catenin [17], resulted in $15.8 \%$ or $57 \%$ of mice developing adult GCTs respectively.

Here, for the first time, we address the importance of APC2 in ovarian folliculogenesis, fertility and GCT formation. The ability of APC2 to regulate the $\beta$-catenin/ WNT signalling pathway has been demonstrated in Drosophila and in cancer cell lines [21-25]. Structurally, APC2 possesses AXIN1 and $\beta$-catenin binding sites, which enable it to destabilize $\beta$-catenin, targeting it for degradation and suppressing its transcriptional activity $[22,26]$, in addition to the APC-basic domain which enables it to regulate cytoskeleton and microtubule association [27-31] and spindle anchoring during mitosis [32]. Importantly, however, in an in vivo setting, APC2dependent regulation of WNT signalling is tissuespecific, occurring in the liver and intestine but not in the mammary gland [33,34]. Little is known about how APC2 functions in adult ovaries, but APC2 loss has been reported in epithelial ovarian cancer $[28,35]$. Here, we show that Apc2-knockout mice [36] have a subfertility phenotype associated with an activation of ovarian WNT signalling, and that, on a hypomorphic Apc background $[37,38]$, loss of APC2 increases the incidence of ovarian GCTs which recapitulate the histologic pattern and molecular signature of human adult GCTs. Not only does this study extend our understanding of the tissuespecific regulation of WNT signalling, but also the APC2-deficient mouse has excellent potential as a preclinical model to study ovarian tumour biology and for therapeutic testing.

\section{Methods}

\section{Animal models, fertility and ovulation rate}

All experiments were carried out under the authority of UK Home Office personal and project licences and according to ARRIVE guidelines and following local ethical review. Mouse models were maintained on a mixed C57B16/J and 129/Ola background in open cages with ad libitum access to food and water. Genotyping for the constitutive knockout allele of $A p c 2\left(A p c 2^{-}\right)$and the hypomorphic allele of $A p c\left(A p c^{f l}\right)$ [34, 36-38] were performed as previously described [34, 36] (Additional file 1: Table S1). Typically, experiments compared wild type, heterozygous Apc2-deleted and homozygous-Apc2 deleted mice, with a minimum of three animals per groups, unless otherwise specified. The breeding defect of $A p c 2$ knockout animals made it difficult, in some cases, to use large $\mathrm{n}$ numbers for analysis; where this is the case it has been clearly indicated in the text. Animals were euthanased for analysis of ovarian tissue by an approved humane method (cervical dislocation) at the times indicated (typically 10 weeks old for functional analysis and 12 or 18 months for tumour studies).

To assess female fertility, retrospective analysis of breeding performance was analysed from cages in which two 7-11 week-old female mice of the experimental genotypes $\left(A p c 2^{+/+}, A p c 2^{+/-}\right.$and $\left.A p c 2^{-/-}\right)$were housed with a 7-9 week-old male of the same genotype for 3 months $(n=4$ cages $)$. Litter sizes were determined at the time of weaning.

To determine ovulation rates, 10 week-old female mice were super-ovulated by a single intraperitoneal injection of $5 \mathrm{IU}$ pregnant mare's serum gonadotrophin (MSD animal health, UK), followed by $5 \mathrm{IU}$ human chorionic gonadotrophin (MSD animal health, UK), $47 \mathrm{~h}$ later [39]. Mice were either euthanased 16-17 (for Cumulus Oophorus Complex retrieval) [40] or 22-24 h later (for histological analysis) by an approved humane method (cervical dislocation).

\section{Cumulus Oophorus complex (COC) retrieval and characterization}

After release from the oviducts, COCs were counted and examined by bright-field microscopy to assess morphology. Oocytes were freed from surrounding cumulus cells by addition of $40 \mu \mathrm{l}$ of $4 \mathrm{mg} / \mathrm{ml}$ collagenase/dispase (Roche, Switzerland), dissolved in DMEM/F12 medium (Mediatech, USA), for $10 \mathrm{~min}$, and examined to determine their integrity [41] and to measure their diameter [42]. 


\section{Histological analysis of ovaries}

Follicle counting was performed on ovaries from 10week-old $A p c 2^{+/+}$and $A p c 2^{-/-}$mice, either from randomly cycling females staged manually (using the vaginal cytology method) and collected at diestrus stage $(n=4)$ or $22-24 \mathrm{~h}$ post HCG administration $(n=5)$. Each ovary was serially-sectioned into $1005 \mu \mathrm{M}$ sections and each 10th section was stained with $\mathrm{H} \& \mathrm{E}$. Growing follicles were counted every 10th section, when an oocyte nucleus was visible. Identification and classification of growing follicles and atretic follicles were performed as previously described [43, 44]. The total number of follicles throughout the 10 counted sections was used. Follicle sizes were measured using a minimum of 4 diameters/follicle.

\section{Hormonal analysis}

Serum hormonal levels were measured in 10-week-old $A p c 2^{+/+}$and $A p c 2^{-/-}$mice at diestrus stage using ELISA kits for FSH (Novateinbio, USA) and LH (Enzo Lifesciences, UK).

\section{Immunohistochemistry}

Tissue sectioning and immunohistochemistry were performed as previously described [34], using primary antibodies listed in Additional file 1: Table S2. Sections were examined with an Olympus BX43 light microscope and microphotographs taken using a 5 Megapixel HD Microscope Camera (Leica MC170 HD, Germany).

\section{Quantitative RT-PCR analysis}

RNA was extracted from whole ovaries or tumour pieces using RNeasy Plus mini extraction kit (Qiagen, Germany) and reverse transcription performed using QuantiTect Reverse transcription kit (Qiagen, Germany). All quantitative real time rtPCR assays were carried out three times using $\operatorname{TaqMan}^{\odot}$ universal master mix II with UNG (Applied Biosystems, USA), Taqman ${ }^{\circledR}$ assays (Additional file 1: Table S3) and QuantStudio ${ }^{\text {тx }} 7$ Flex Real Time PCR system (ThermoFisher, USA), and relative expression levels determined using QuantStudio ${ }^{\text {тм }} 7$ Real Time PCR software.

\section{Statistical analysis}

Statistical significance for qRT-PCR data was determined from 95\% confidence intervals [45]. All other statistical analyses were performed using IBM SPSS version 20 (SPSS Inc., Chicago, IL, USA). Significance testing was performed using 2-tailed Student's t-test, when 2 experimental cohorts were compared. When more were compared, ANOVA test was used, followed by a post-hoc test (LSD or Games-Howell). P-values of $<0.05$ were considered statistically significant.

\section{Results}

APC2 deficiency results in sub-fertility

To evaluate the role of APC2 in the biology of the adult ovary, the impact of APC2 deficiency on normal ovarian homeostasis and fertility was first assessed. A retrospective analysis of mating efficiencies of wild type, heterozygous or homozygous breeding trios $\left(A p c 2^{+/+}, A p c 2^{+/-}\right.$or $A p c 2^{-/-}$respectively) demonstrated that time between pairing mice and first litter production was significantly longer in $A p c 2^{-/-}$mice (Fig. 1a). The number of gestations over the 3-month period following pairing was significantly reduced in $A p c 2^{-/-}$mice, with heterozygous mice also showing a reduction which did not reach significance (Fig. 1b). Overall, there was a $40 \%$ reduction in the cumulative number of pups weaned over 3 months from $A p c 2^{+/-}$trios, compared to $A p c 2^{+/+}$, and this reduction was even more pronounced in $A p c 2^{-/-}$mice (Fig. 1c). Indeed, one $A p c 2^{-/-}$trio was completely infertile over this period.

Histology of ovaries, oviducts and uteri from 10-weekold virgin $A p c 2^{+/+}$and $A p c 2^{-/-}$mice revealed no gross morphological differences in the oviducts and uteri (representative images in Additional file 2: Figure S1). No problems were reported during labour in any of the experimental groups; it is therefore unlikely that uterine problems contribute to the observed subfertility phenotype. However, there was a significant decrease in the number of corpora lutea formed in $A p c 2^{-1-}$ ovaries (Fig. $1 d$, e \& f), while the total number of growing follicles was increased, but not significantly (Fig. 1g). Morphometric and histochemical analysis of corpora lutea did not reveal any histological differences in these structures between $A p c 2^{+/+}$and $A p c 2^{-/-}$ovaries (Additional file 3: Figure S2). Collectively, these findings suggest reduced ovulation is the cause of the subfertility observed in APC2-deficient mice.

\section{Subfertility in APC2-deficient female mice is caused by intra-ovarian defects}

Given the constitutive nature of the $A p c 2$ gene deletion in our mice, the genotype dose-dependent reduction in fertility, potentially as a result of an ovulation defect, may be due to defects in extra-ovarian regulation of ovarian function, triggered by hypothalamic/pituitary endocrine signals. To address this, follicle stimulating hormone $(\mathrm{FSH})$ and luteinizing hormones $(\mathrm{LH})$ levels in serum from 10 -week old virgin $A p c 2^{+/+}$and $A p c 2^{-/-}$female mice at diestrus stage were analysed by ELISA, but showed no differences (Additional file 4: Figure S3)a, b, suggesting hypothalamic/pituitary signals are not affected by Apc2 deletion.

Next, to determine whether the response of the ovary to endocrine signals was compromised in the context of Apc2 deletion, exogenous gonadotrophins were administered to 

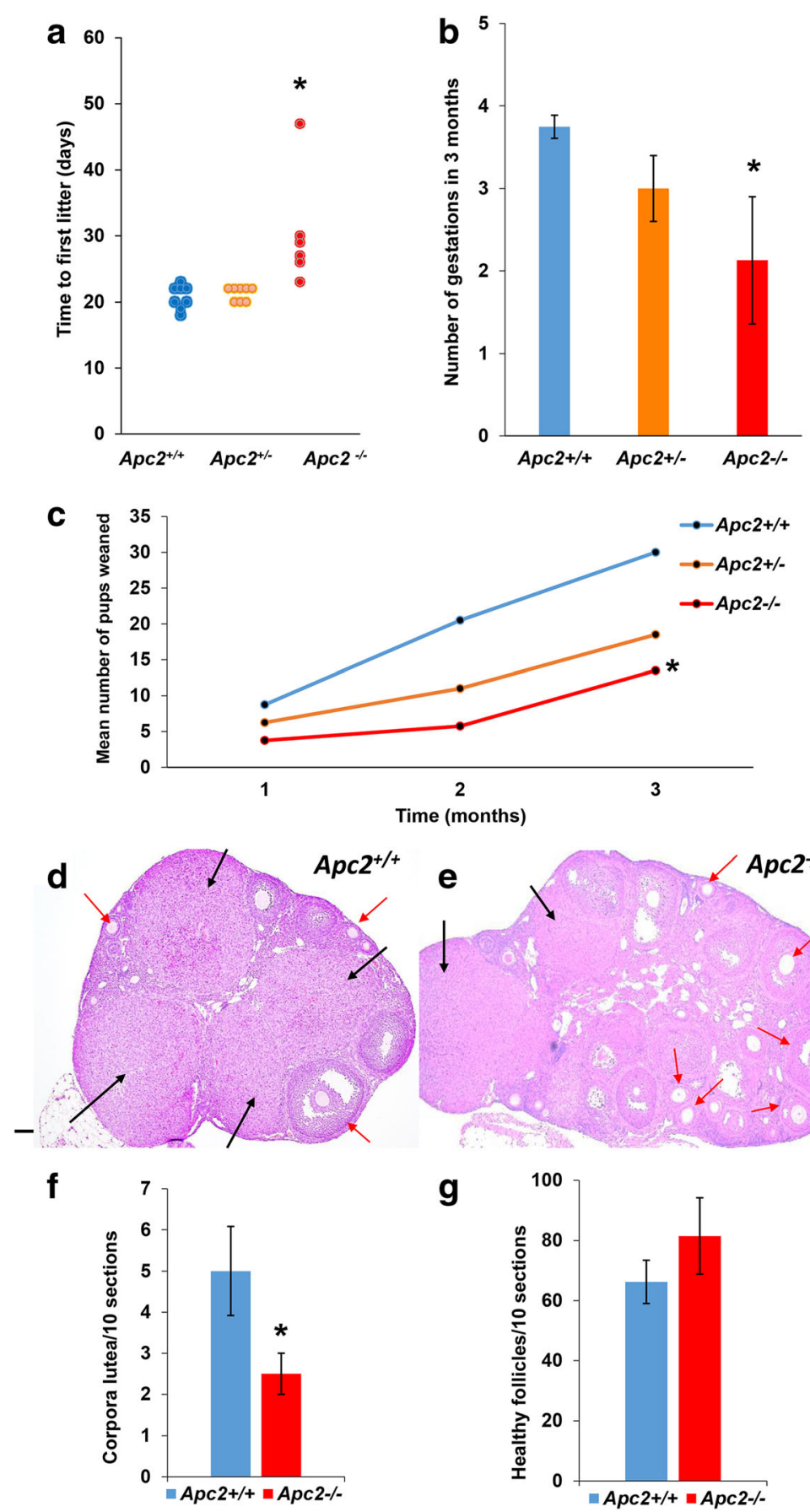

Fig. 1 APC2 loss causes subfertility in adult female mice. a Mating efficiency of Apc2 experimental genotypes as a function of time recorded in days between pairing the mice and delivering the first litter. $N=4$ breeding cages each with one $A p C 2^{+/+}, A p C 2^{+-}$or $A p c 2^{-1-}$ male $\mathrm{crossed}$ with $2 \mathrm{ApC2}^{+/+}, 2 \mathrm{ApC2^{+/- }}$ or $2 \mathrm{Apc}^{-/-}$female respectively. One $A p 2^{-1-}$ trio was completely sterile $\left({ }^{*} P<0.05\right)$. b Breeding efficiency as reflected by number of gestations occurring in a 3 month period (mean \pm S.E, $n=4$ ). c Cumulative number of pups weaned in a 3 month period from 4 breeding pairs. Statistical significance between groups was determined using ANOVA test followed by Games-Howell post hoc analysis (variances of experimental groups were not homogeneous, tested by Levene's test). d, e Representative photomicrographs of (d) $A p c 2^{+/+}$and (e) $A p c 2^{-/-}$ ovaries, showing growing follicles (red arrows) and corpora lutea (black arrows). Bar $=500 \mu \mathrm{m}$. f, $\mathbf{g}$ Histograms showing total number of (f) corpora lutea, and $\mathbf{( g )}$ healthy growing follicles, counted across 100 serial sections of four ovaries collected from four animals at diestrus stage (mean $\pm \mathrm{SE}^{*}{ }^{*} P<0.05$, t-test) 
induce superovulation in 10 -week-old virgin $A p c 2^{+/+}$, $A p c 2^{+/-}$and $A p c 2^{-/-}$mice. There was a gene dosedependent decrease in the number of cumulus oophorus complexes (COCs) collected from the ampulla postsuperovulation (Fig. 2a). However, morphological analysis of the COCs demonstrated that all oocytes were of comparable size, surrounded by a layer of cumulus cells of comparable thickness, and were healthy, with no signs of fragmentation, irrespective of genotype (Fig. 2b, c).

Importantly, histological analysis post-superovulation demonstrated a significant reduction in the number of corpora lutea in super-ovulated $A p c 2^{-/-}$ovaries compared to $\mathrm{Apc}^{+/+}$(Fig. 2 d,e\&f). As with unstimulated ovaries, a slight, but non-significant, increase in the number of healthy growing follicles in $\mathrm{Apc}^{-1-}$ ovaries was observed (Fig. 2d,e\&g). Taken together, these findings suggest that the subfertility phenotype seen in APC2-deficient female mice is not due to extra-ovarian defects in pituitary gonadotrophin secretion, but rather due to intra-ovarian defects in response to gonadotrophins that result in reduced ovulation. Therefore, expression levels of the ovarian gonadotrophin receptors Fshr and Lhcgr, together with the steroid hormone receptors Pgr, Esr1, Esr2 and Ar, were assessed in ovaries from $A p c 2^{+/+}$and $A p c 2^{-/-}$mice. Significant overexpression of $L h c g r$ was evident in $A p c 2^{-/-}$ovaries (Fig. $2 \mathrm{~h}$ ), but the other receptors were unaltered. Importantly, the LH receptor is a target of canonical WNT signalling [46], and its over-expression has previously been associated with infertility in mice [47].

Detailed morphometric analysis, on serial-sectioned ovaries collected at diestrus stage from $\mathrm{Apc}^{+/+}$and $A p c 2^{-1-}$ mice, demonstrated that the trend for an increase in the total number of healthy growing follicles in $A p c 2^{-/-}$ovaries (Fig. 1g), was restricted to the number of primary and antral follicles (Fig. 3a). Size distribution analysis for healthy antral and pre-ovulatory follicles demonstrated a significant increase in the percentage of small follicles (diameter $<200 \mu \mathrm{m}$ ) and a significant decrease in the percentage of larger follicles (diameter $>$ $300 \mu \mathrm{m}$ ) in $A p c 2^{-/-}$ovaries (Fig. 3b). Analysis of atretic follicles was undertaken to determine whether increased atresia was causing the reduction in larger follicles in $A p c 2^{-/-}$ovaries, but their total number and size distribution were not significantly altered (Additional file 4: Figure S3)c,d. IHC for Ki67 revealed that proliferation was unaltered in follicular granulosa or theca cells (Additional file 4: Figure S3). However, apoptosis, as measured by cleaved caspase $3 \mathrm{IHC}$, was significantly increased in granulosa cells in $A p c 2^{-/-}$follicles (Fig. 3c, $\mathrm{d} \& \mathrm{e})$. Histological analysis of pre-ovulatory follicles together with gene expression analysis of EFG ligands and receptor did not reveal defects in ovulation (Additional file 4: Figure S3)f,g. Thus, APC2 deficiency increases granulosa cell apoptosis, restricting follicular growth and reducing their ability to reach the pre-ovulatory stage.

\section{APC2 deficiency activates ovarian WNT signalling and upregulates Foxo1 expression}

As APC2 is a known regulator of canonical WNT signalling, we investigated whether dysregulated WNT signalling was mechanistically linked to the restriction in follicular growth in $A p c 2^{-/-}$ovaries. Ovarian subcellular localization of $\beta$-catenin was assessed by immunohistochemistry (IHC), and expression of a standard panel of WNT target genes was determined by qRT-PCR, using whole ovaries collected at diestrus stage from 10-weekold virgin control $\left(A p c 2^{+/+}\right)$and APC2-knockout $\left(A p c 2^{-/-}\right)$mice. IHC analysis of $\beta$-catenin revealed a comparable pattern of expression in all ovarian compartments between control and knockout ovaries (Additional file 5: Figure S4), although increased staining intensity was notable in atretic follicles from $A p c 2^{-/-}$ovaries (Fig. 4a). qRT-PCR analysis revealed a significant increase in the expression levels of Apc, Axin2, Ctnnb1, Fgf1 and $L g r 5$ in $A p c 2^{-1-}$ ovaries compared to control ovaries (Fig. 4b). However, there were no significant changes in Cd44, Lef1 and Wif1.

Given the established role of the FOX family of transcription factors as regulators of apoptosis within ovarian granulosa cells [48-50], and their increased expression in granulosa cells of cultured follicles postWNT signalling activation [51, 52], gene expression levels for Foxo1, Foxo3 and Foxl2 were analysed in $A p c 2^{+/+}$and $A p c 2^{-/-}$whole ovaries. A significant increase in Foxo1 expression levels was seen in $A p c 2^{-/-}$ ovaries (Fig. 4c). Furthermore, the FOXO target genes $B c l 6$ and $C d k n 1 b$ were significantly upregulated in $A p c 2^{-1-}$ ovaries compared to controls (Fig. 4d).

The PTEN/PI3K/AKT signalling pathway is an established regulator of FOXO transcriptional activity and post-translational modification [53]. On activation of AKT, FOXO proteins are inactivated by phosphorylation and translocated from nucleus to cytoplasm [53]. In addition, the crosstalk between activated WNT signalling and PTEN, causing the over-expression of the latter, is well established [16, 17, 54]. IHC analysis of PTEN, p-AKT and p-FOXO1,3,4 in $\mathrm{Apc}^{+/+}$and $A p c 2^{-1-}$ ovaries revealed that PTEN expression was stronger in theca and granulosa cells of $A p c 2^{-/-}$follicles (Fig. 4e). This was accompanied by a reduction in $\mathrm{p}$ AKT immunostaining in $A p c 2^{-/-}$granulosa cells (Fig. 4f) and a consequent reduction in p-FOXO1,3,4 levels (Fig. 4g). Thus, the increased apoptosis seen in $A p c 2^{-/-}$ follicles is likely due to upregulation of Foxo1 and its downstream effector genes, secondary to decreased activation of PI3K/p-AKT signalling caused by PTEN upregulation. 


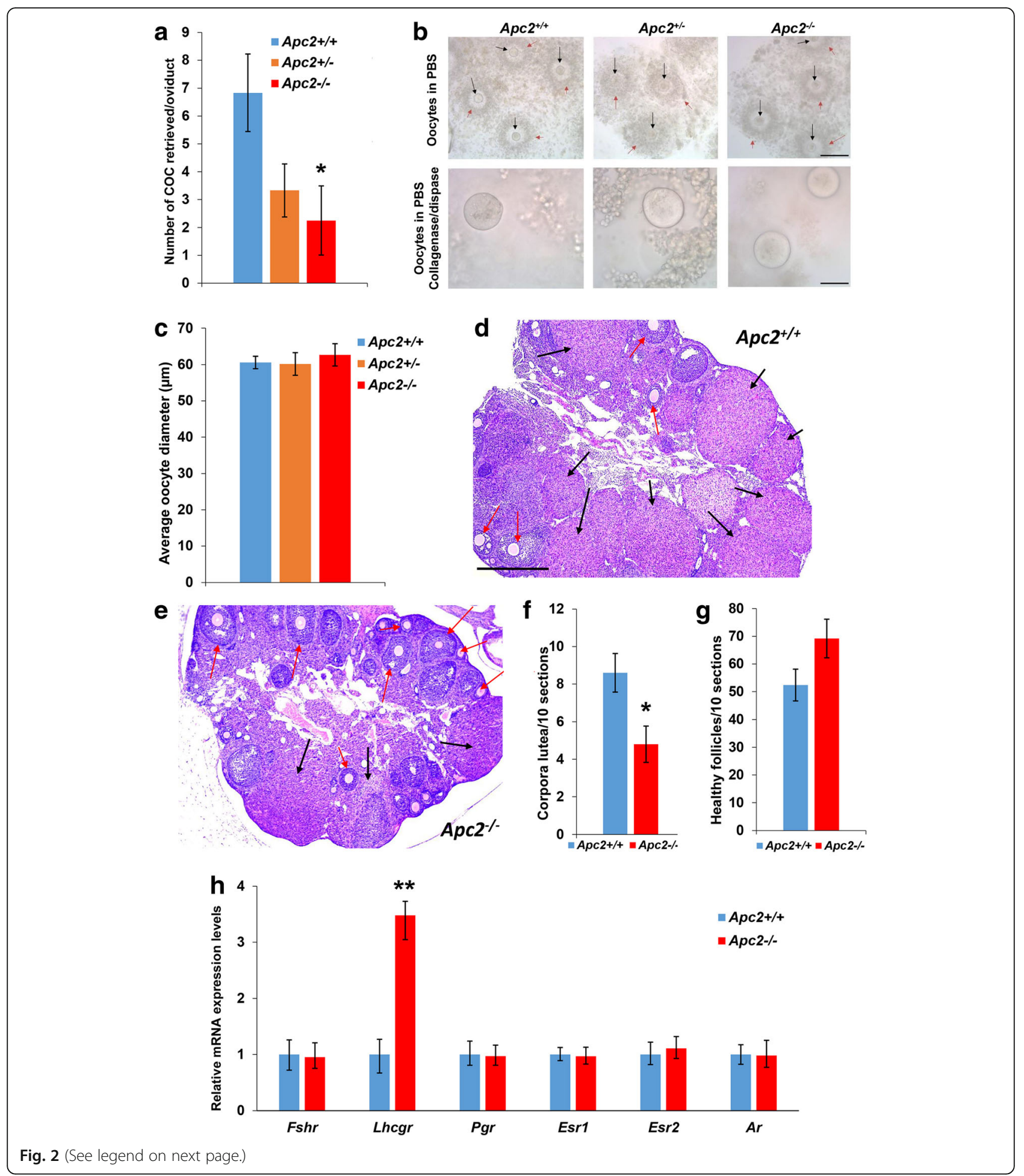

APC2-deficient ovaries show impaired vascularisation and steroidogenesis

Interaction between $\beta$-catenin and FOXO1 has been previously described to affect tight junctions in endothelial cells disrupting angiogenesis [55]. Follicular growth impairment has been shown to occur following angiogenesis disruption, because the vascular network surrounding the growing follicles is essential for follicular development [56]. IHC for CD34 was used to compare follicular vascularization between $A p c 2^{+/+}$and $A p c 2^{-/-}$ovaries. While late antral/pre-ovulatory follicles in $A p c 2^{+/+}$ovaries were surrounded by 2 continuous layers of endothelial 
(See figure on previous page.)

Fig. 2 Exogenous gonadotrophin administration fails to reverse ovarian subfertility of APC2-deficient female mice. a APC2-deficiency caused a gene dose-dependent decrease in the number of ovulated COCS (mean $\pm \mathrm{SE}$ ) retrieved from the oviducts post-superovulation. $\mathbf{b}$ Upper panels, representative photomicrographs of retrieved COCs showing the presence of oocytes (black arrows) surrounded by cumulus cells (red arrows). Bar $=200 \mu \mathrm{m}$. Lower panels, oocytes freed from cumulus cells. Bar $=50 \mu \mathrm{m}$. c Average oocyte diameter (mean \pm SE) among experimental groups, showing no difference. $\mathrm{n}=4$ for $A p \mathrm{C}^{+/+}, n=3$ for $A p c 2^{+/-}, n=5$ for $A p c 2^{-/-}$. Statistical significance between groups in panels a $-\mathrm{c}$ was determined using ANOVA test followed by LSD post hoc analysis (variances of experiment groups were homogeneous tested by Levene's test). d, e Representative photomicrographs of (d) $A p C 2^{+/+}$, and (e) $A p C 2^{-/-}$superovulated ovaries, showing growing follicles (red arrows) and corpora lutea (black arrows). Bar $=500 \mu \mathrm{m}$. $\mathbf{f}, \mathbf{g}$ Total number of (f) corpora lutea, and $\mathbf{( g )}$ healthy follicles counted across 100 serial sections of five superovulated stage-matched ovaries from different animals (mean $\pm \mathrm{SE}$; ${ }^{*} P<0.05$, t-test). $\mathbf{h}$ Gene expression levels of hormone receptors by qRTPCR on RNA extracted from whole ovaries of $A p C 2^{+/+}$and $A p C 2^{-/-} 10$-week-old female mice. Relative expression levels are normalized to Actb expression. $N=4$ except for Ihcgr and $\mathrm{Ar}$ in $A p \mathrm{C}^{-/-}$where $\mathrm{n}=3$ (mean $\pm 95 \%$ confidence intervals; ${ }^{* *} P<0.01$, determined from confidence intervals) [45]
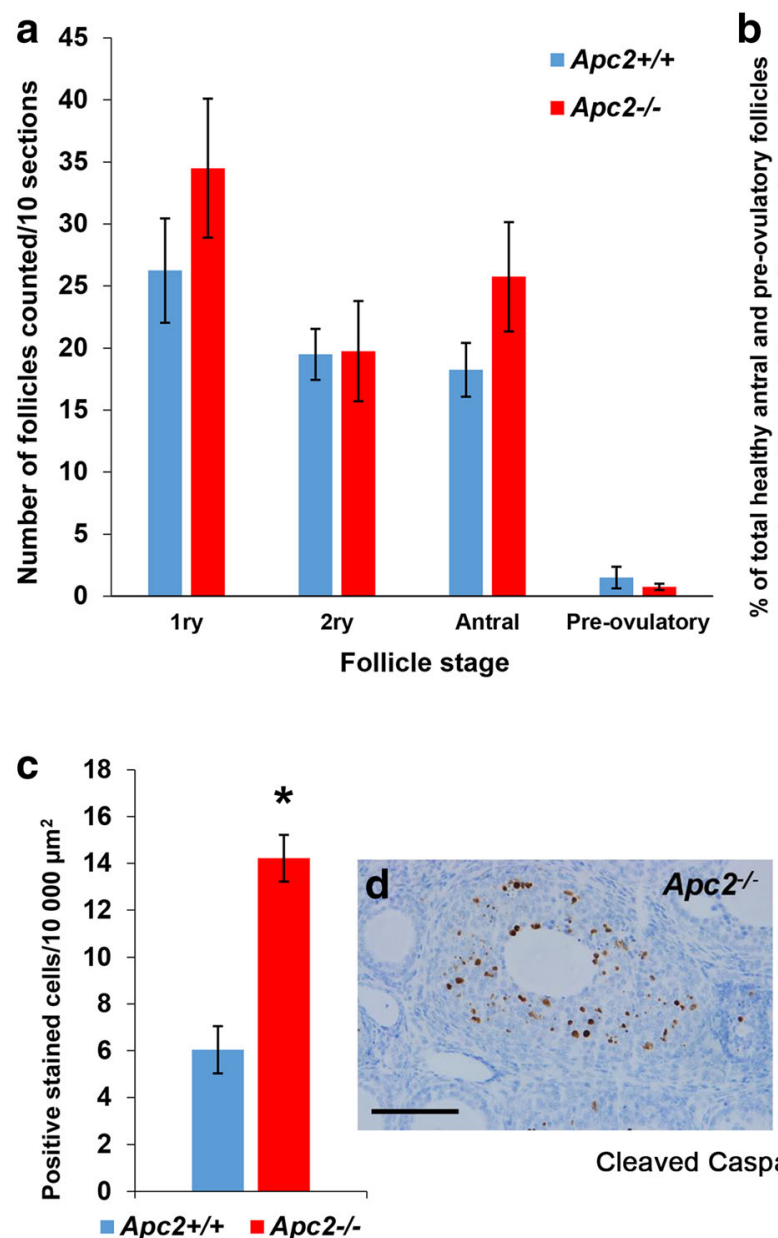

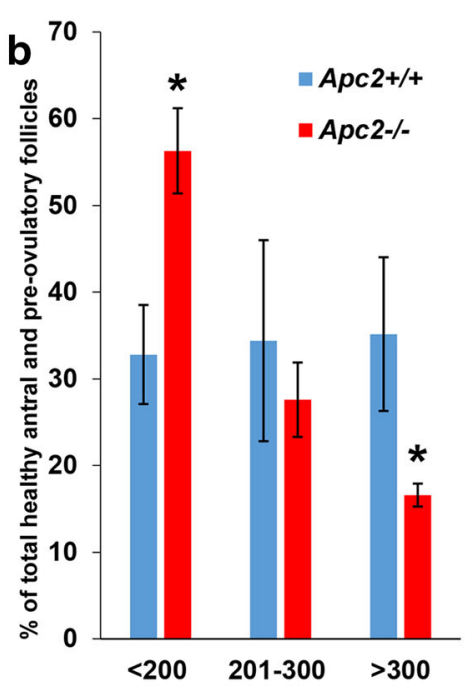

Follicle diameter $(\mu \mathrm{m})$

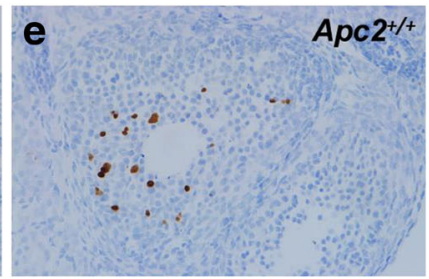

Cleaved Caspase 3 staining

Fig. 3 APC2-deficiency impairs follicular growth in the ovary. a Histogram showing total number of primary (1ry), secondary (2ry), antral and preovulatory follicles in $\mathrm{ApC2}^{+/+}$and $A p c 2^{-/-}$ovarian sections (mean $\pm \mathrm{SE} ; n=4$; no significant differences, t-test). $\mathbf{b}$ Size distribution of healthy antral and pre-ovulatory follicles (mean $\pm \mathrm{SE} ; n=4$; ${ }^{*} P<0.05$, t-test). $\mathbf{c}$ Histogram showing a $>2$-fold increase of apoptosis in granulosa cells of Apc2 ${ }^{-1-}$ follicles (mean $\pm \mathrm{SE} ; n=4$; ${ }^{*} P<0.05$, t-test). $\mathbf{d}$, e Representative photomicrographs of cleaved caspase 3 immunostaining in (d) $A p c 2^{-1-}$ and (e) Apc2 ${ }^{+/+}$granulosa cells. Bars $=100 \mu \mathrm{m}$ 


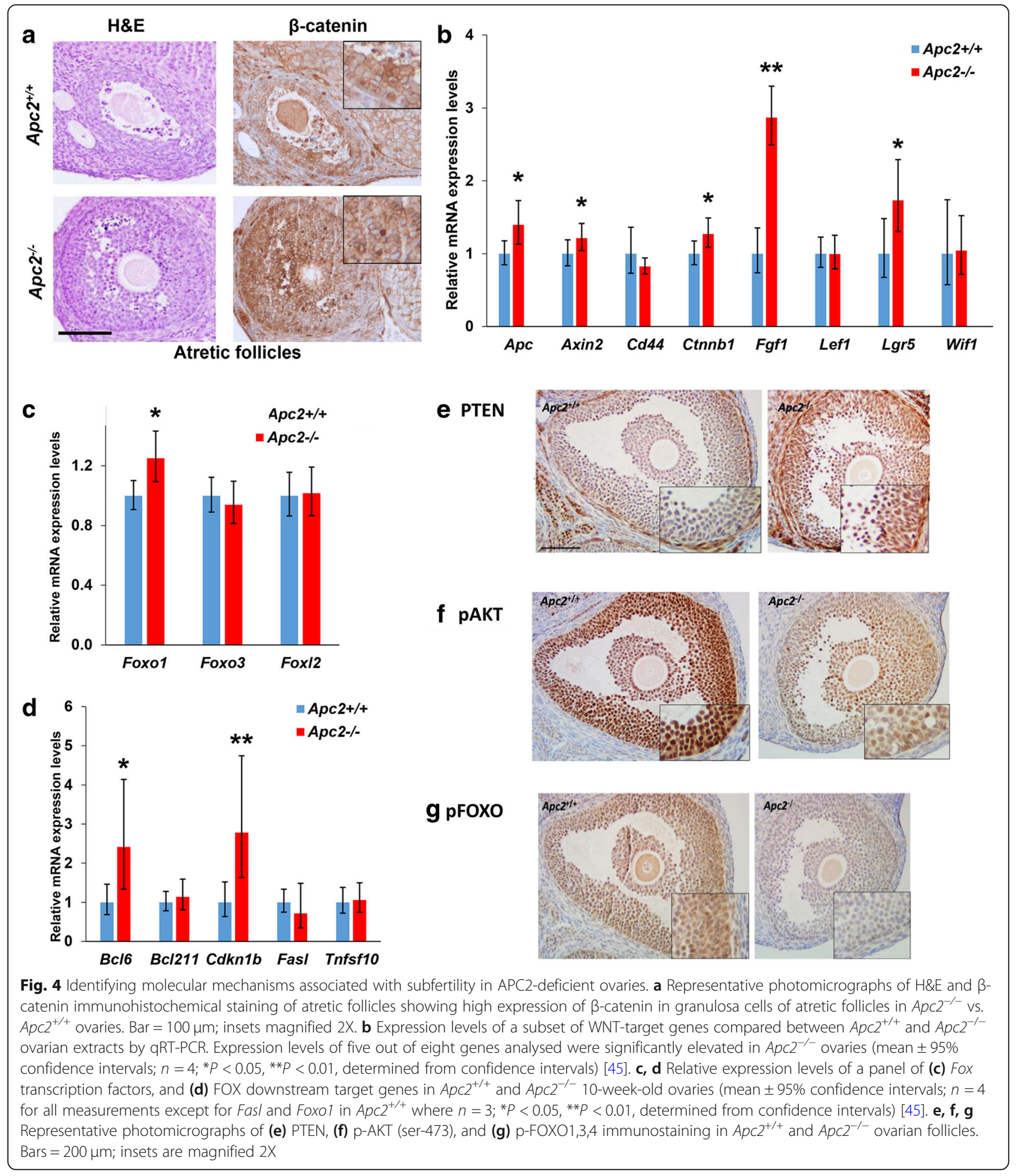

cells, those in $A p c 2^{-/-}$mice showed discontinuous layers (Fig. 5a). Furthermore, a significantly reduced level of Vegfa expression (Fig. 5b) supports the notion of impaired vascularisation within $A p c 2^{-/-}$ovaries, although it could, in part, be attributed to the reduced number of corpora lutea.
Negative regulation of follicle steroidogenesis by canonical WNT signalling has also previously been demonstrated [52]. We therefore examined the expression of key enzymes required for steroidogenesis in Apc2 knockout ovaries. We found there was significantly reduced expression of both Cyp17a1 (coding for steroid 17- $\alpha$ - 

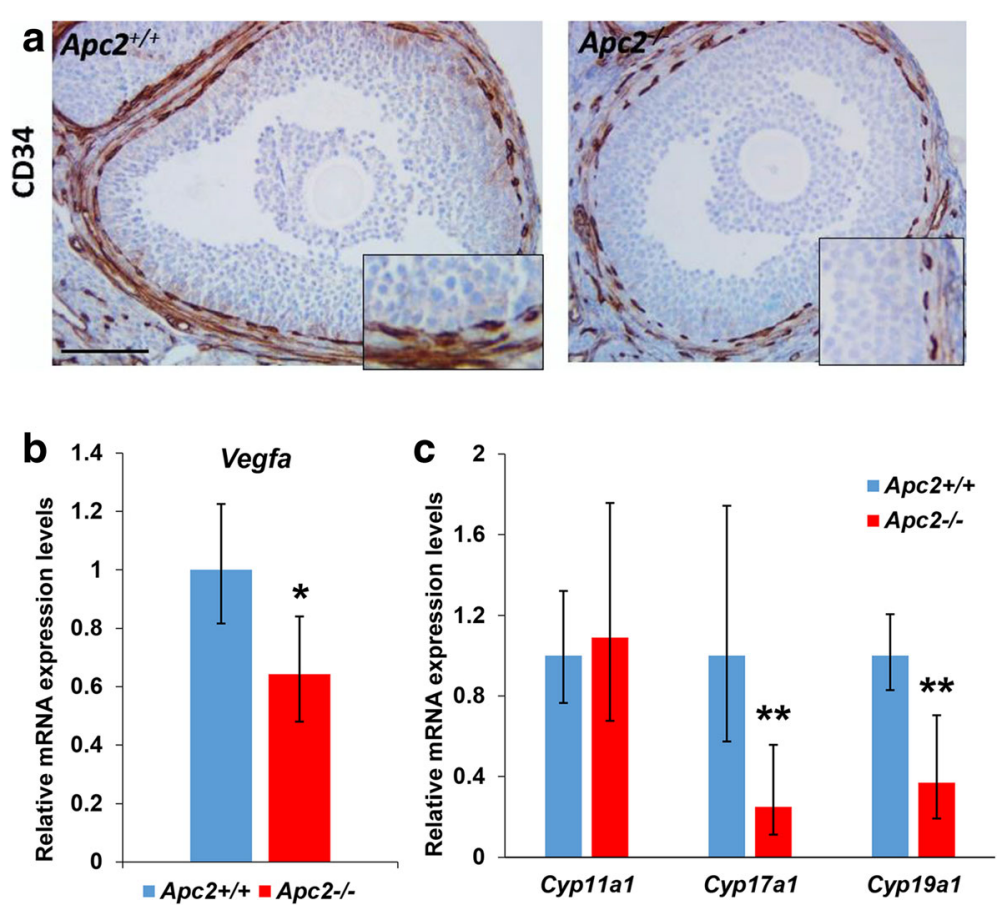

Fig. 5 APC2 loss impairs follicle steroidogenesis and vascularization. a Representative photomicrographs of CD34 immunostaining of follicles in $A p c 2^{+/+}$and $A p c 2^{-/-} 10$-week-old ovaries. Bars $=100 \mu \mathrm{m}$; insets are magnified 2X. b, c Gene expression levels of (b) Vegfa, and (c) steroidogenic enzymes by qRT-PCR on ovaries of 10-week-old $A p c 2^{+/+}$and $A p c 2^{-/-}$female mice (mean $\pm 95 \%$ confidence intervals; $n=4$ for all measurements except for Cyp19a1 in $A p c 2^{-/-}$where $n=3 ;{ }^{*} P<0.05,{ }^{* *} P<0.01$, determined from confidence intervals) [45]

hydroxylase/17,20 lyase) and Cyp19a1 (coding for aromatase) in $A p c 2^{-/-}$ovaries compared to $A p c 2^{+/+}$ovaries (Fig. 5c).

Therefore, activation of WNT signalling in Apc2 knockout ovaries results in overexpression of PTEN and a reduction in activity of steroidogenesis and angiogenic pathways. These metabolic defects combine to result in a reduced number of follicles maturing to the ovulatory stage.

\section{Long-term activation of WNT signalling by APC/APC2 deficiency, results in ovarian adult granulosa cell tumour formation}

Because of the WNT signalling-dependent defects observed in 10-week-old Apc2 knockout mice, and the potential role of WNT signalling in driving ovarian tumour development in mice $[15,17,54,57,58]$, we aged for up to 18 months cohorts of mice in which WNT signalling was activated to different levels using a hypomorphic $A p c$ allele (weak activation of canonical WNT signalling), hypomorphic $A p c$ plus $A p c 2^{+/-}$knockout (moderate activation) or hypomorphic $A p c$ plus $A p c 2^{-1-}$ knockout (strong activation). No gross ovarian tumours were detected in any cohorts at 6 months of age; however 6/29 (20.7\%) of the APC2-deficient cohorts $\left(A p c 2^{+-}\right.$and $A p c 2^{-1-}$ cohorts on the background of hypomorphic Apc) had developed adult ovarian GCTs at 12-18 months of age as compared to $1 / 19$ (5.26\%) of the APC2-proficient (hypomorphic Apc only) cohort developing ovarian GCT at 18 months of age (Table 1).

The tumours ranged from small microscopic in situ tumours to large macroscopic tumours (Fig. 6a-e). Morphologically, they recapitulated human ovarian adult GCTs and showed a range of different histological patterns (Fig. 6f-l). Cells were highly anaplastic (Fig. 6m) and mitotic figures were evident (Fig. 6n). Call-Exner bodies (formed of follicle remnants, Fig. 6j,o) and coffee bean-shaped nuclei (Fig. 6o), both characteristic of adult GCTs, were occasionally present.

The molecular signature of the tumours was assessed by IHC for markers associated with human adult GCTs. Marker expression patterns in tumours derived from 12

Table 1 Frequency of GCT formation in 12 and 18-month-old Apc2 experimental genotypes on the background of $A p c^{f / / f l}$. *One animal developed bilateral tumours

\begin{tabular}{lll}
\hline Age (months) & Genotype & Frequency of ovarian GCT \\
\hline 12 & $A p c 2^{+/+}$ & $0 / 10(0 \%)$ \\
12 & $A p C 2^{+/-}$ & $0 / 4(0 \%)$ \\
12 & $A p C 2^{-/-}$ & $2^{*} / 10(20 \%)$ \\
18 & $A p C 2^{+/+}$ & $1 / 9(11.1 \%)$ \\
18 & $A p c 2^{+/-}$ & $3 / 9(33.3 \%)$ \\
18 & $A p c 2^{-/-}$ & $1 / 6(16.67 \%)$ \\
\hline
\end{tabular}



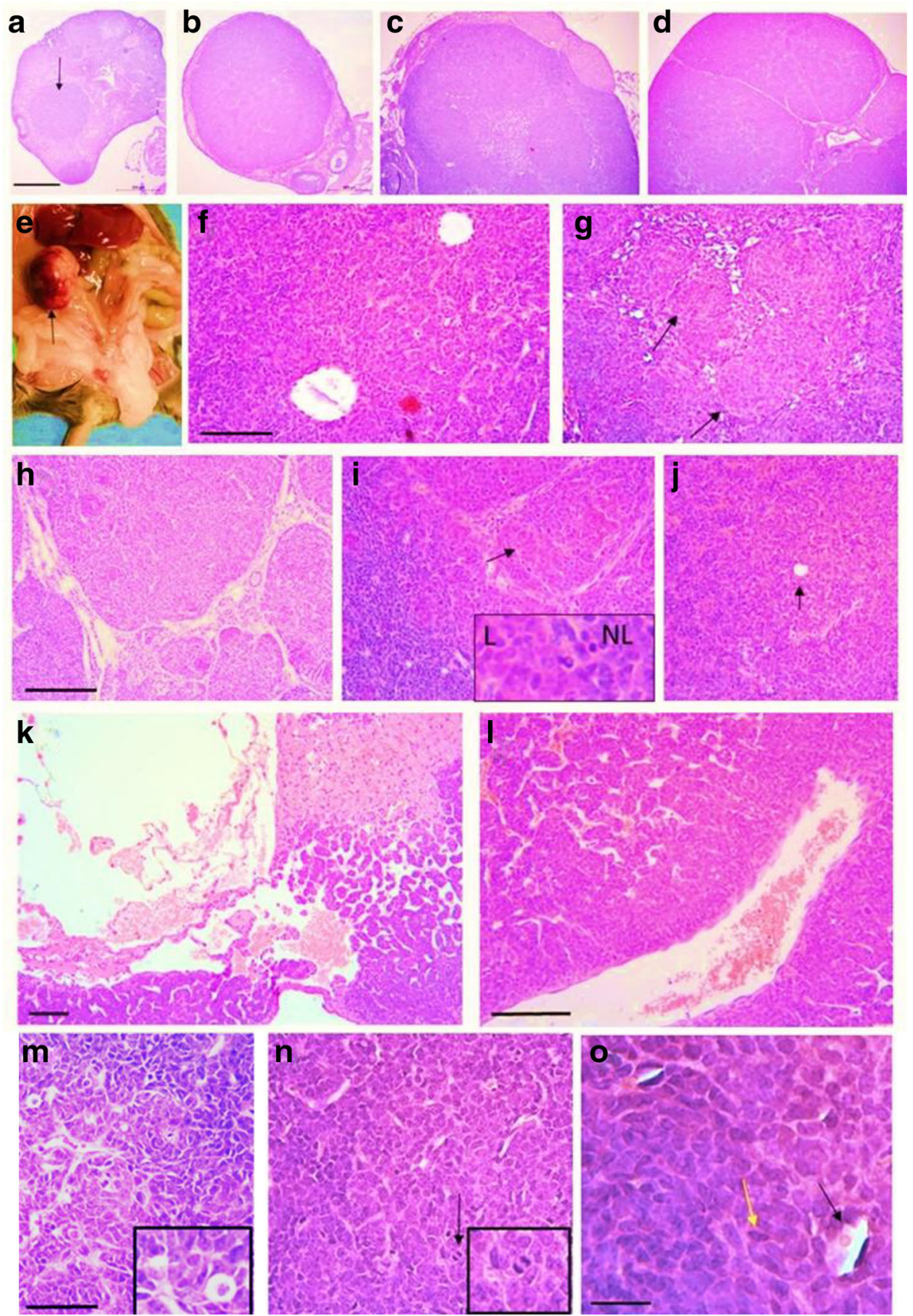

Fig. 6 Aging APC2-deficient mice develop adult GCTs. Tumours ranged in size from (a) small in situ tumours (arrow) to (b) small tumours of normal ovarian size, (c, d) small but macroscopically visible tumours or (e) a large macroscopic tumour (arrow). The tumours displayed varying histologic patterns such as (f) follicular, (g) nodular (arrows), (h) insular, (i) luteinized (arrow: luteinized area shown at 4X original magnification in inset, L: luteinized, NL: non-luteinized), (j) diffuse (arrow: Call-Exner body), and (k) cystic patterns. The tumours were (I) highly vascularized, (m) anaplastic, (n) mitotic (black arrow), and showed (o) Call-Exner bodies (black arrow) and coffee-bean nuclei (yellow arrow). Bars a-d = $500 \mu \mathrm{m}, \mathrm{f}-$ $\mathrm{I}=100 \mu \mathrm{m}, \mathrm{m}-n=50 \mu \mathrm{m}, \mathrm{o}=20 \mu \mathrm{m}$

to 18 month $A p c 2^{+/-}$and $A p c 2^{-/-}$mice were compared with the single GCT which formed in an 18 month $A p c 2^{+/+}$animal (all animals also carrying the hypomorphic Apc allele, as noted above). In general, the expression patterns of most of the markers examined was similar in the $A p c 2^{+/+}, A p c 2^{+/-}$and $A p c 2^{-/-}$tumours (Figs. 7 and 8). Several studies have shown increased FOXL2 protein expression in human GCTs and animal models [59-61], and in agreement with these findings, our GCTs also displayed elevated levels of FOXL2 

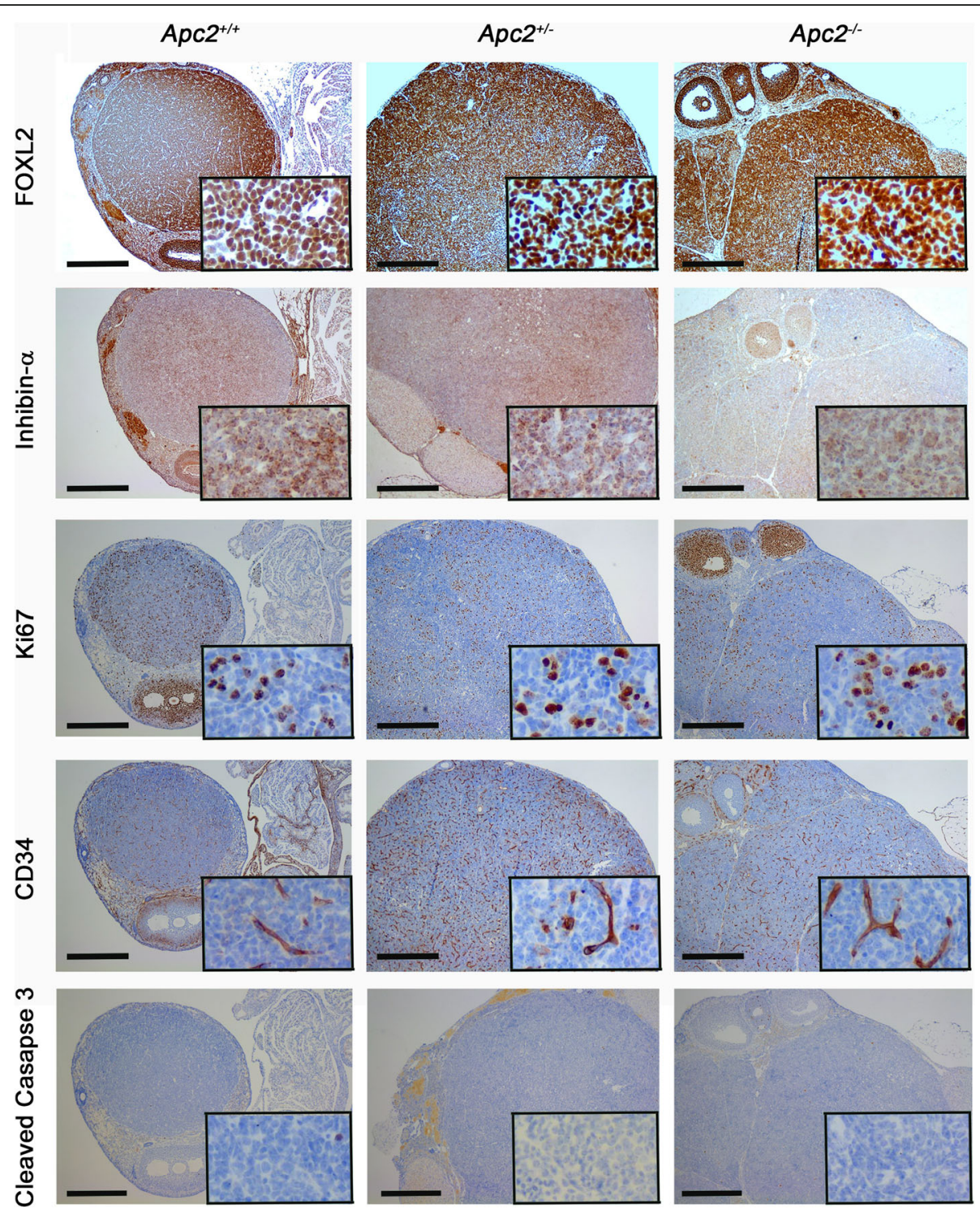

Fig. 7 Molecular characterization (FOXL2, Inhibin-a, Ki67, CD34, cleaved caspase-3) of GCTs developing in aged (12-18 month) Apc2 deficient ovaries. Representative photomicrographs of immunohistochemical staining of GCTs developing in $\mathrm{ApC2}^{+/+}$ovaries (left column) and in $\mathrm{ApC2}^{+/-}$ (middle column) and $\mathrm{ApC2}^{-1-}$ (right column) for FOXL2 protein, Inhibin-a, Ki67, CD34 and cleaved caspase-3 (showing absence of apoptosis in GCT). Note all genotypes also carried an Apc hypomorphic allele. Bar $=500 \mu \mathrm{m}$ for main panel, $50 \mu \mathrm{m}$ for insets. To maintain resolution, insets have been cropped from a representative area of a separate high power photograph, rather than a magnification of the main panel figure

expression (Fig. 7, Additional file 6: Fig. S5)a. The tumours were also positive for inhibin- $\alpha$, which is used in the differential diagnosis of GCTs [62], and which showed focal cytoplasmic staining (Fig. 7). Staining for Ki67, CD34 and cleaved caspase 3 demonstrated the classic hallmarks of proliferation, neovascularization (angiogenesis) and absence of apoptosis respectively, in all GCTs analysed (Fig. 7). Impaired follicular growth in 10-week-old $A p c 2^{-1-}$ ovaries was associated with increased apoptosis (Fig. 3c-e) and Foxo1 expression (Fig. 4c). As apoptosis was reduced in the GCTs from aged mice, we analysed FOXO1 expression levels by IHC and observed a reduction in FOXO1 staining in GCT area as compared to granulosa cells of growing follicles (Fig. 8, follicle indicated by black arrow; Additional file 6: Figure S5)b.

To determine whether active canonical WNT signalling was associated with GCT formation, $\beta$-catenin staining was carried out. Tumour cells strongly expressed $\beta$ catenin in contrast to the expression seen in nontumour areas (Fig. 8; compare $\beta$-catenin staining in tumour area indicated by black arrow with non-tumour area indicated by red arrow). Due to limitation of available tumour samples, qRT-PCR analysis could only be 

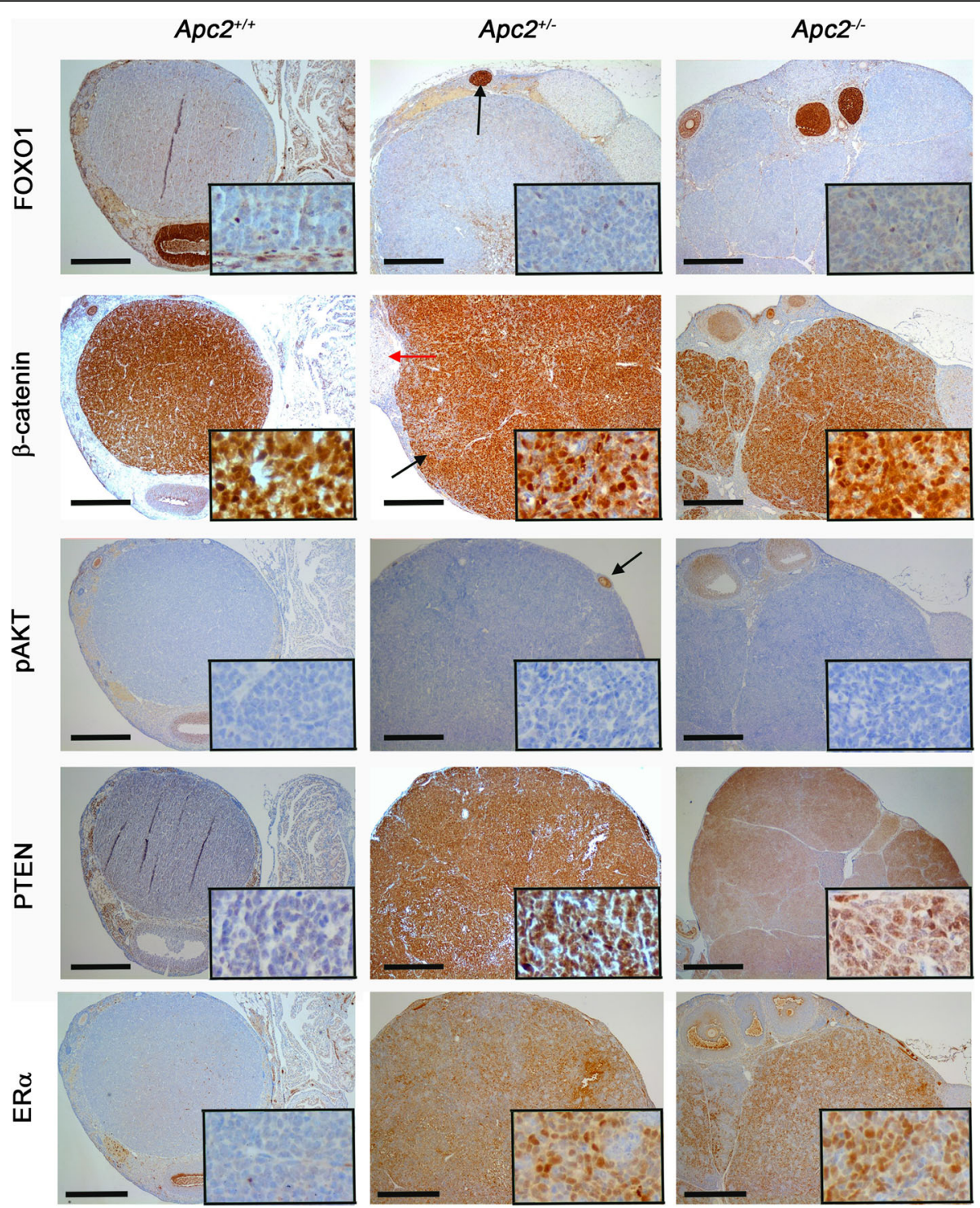

Fig. 8 Molecular characterization (FOXO1, $\beta$-catenin, p-AKT, PTEN, ERa) of GCTs developing in aged (12-18 month Apc2 deficient ovaries. Representative photomicrographs of immunohistochemical staining of GCTs developing in $\mathrm{ApC2}^{+/+}$ovaries (left column) and in $A p c 2^{+/-}$and $A p C 2^{-/-}$(right column) mice for FOXO1 showing weak staining in GCT, in contrast to a growing follicle (black arrow), $\beta$-catenin showing intense staining in GCT (black arrow) as compared to a corpus luteum (red arrow), p-AKT which was absent in GCT as compared to a growing follicle (black arrow), PTEN and estrogen receptor alpha (ERa). Note all genotypes also carried an Apc hypomorphic allele. Bar =500 $\mu \mathrm{m}$ for main panel, $50 \mu \mathrm{m}$ for insets. To maintain resolution, insets have been cropped from a representative area of a separate high power photograph, rather than a magnification of the main panel figure

performed on two WNT signalling target genes (Wif1 and Axin2) using RNA from two Apc2-deficient GCTs, with $A p c 2$-proficient ovaries used as control material. Two independent areas from each tumour were analysed to allow for tumour heterogeneity. Comparison of expression levels demonstrated higher levels of both Wif1 and Axin2 within APC2-deficient tumours (Additional file 6: Figure S5)c,d.

Activation of PI3K/AKT signalling via Pten deletion has been shown to enhance GCT development and progression in mouse models driven by WNT signalling activation [63, 64]. However, phospho-AKT (p-AKT), a marker of active PI3K/AKT signalling, was undetectable within our GCTs (Fig. 8). Furthermore, $\mathrm{Apc}^{+/-}$and $A p c 2^{-/-}$GCTs showed strong PTEN staining, in contrast to no staining in the $A p c 2^{+/+}$tumour (Fig. 8). This likely explains the lack of pAKT staining in the APC2-deficient tumours. However, the lack of both pAKT and PTEN staining in the $\mathrm{Apc}^{+/+}$tumour may result from the hypomorphic APC allele on its own being an insufficiently 
strong driver of WNT signalling to activate PI3K/AKT signalling via established cross-talk mechanisms [65].

Estrogen receptor alpha (ER $\alpha)$ also showed differential staining between APC2-deficient tumours compared to the APC2-proficient tumour analysed. Human ovarian GCTs are also characterized by frequent focal staining for estrogen receptor alpha (ER $\alpha)$ (Fig. 8; Additional file 6: Figure S5)e which suggests that APC2 deficiency not only increases the frequency of GCTs in mice which also carry a hypomorphic Apc allele, but also results in tumours with a greater histological and molecular similarity to human GCTs.

\section{Discussion}

This study has revealed that APC2-deficiency activates WNT signalling in the ovary during early adulthood, which subsequently disrupts ovarian homeostasis and causes subfertility originating from an ovarian defect. Follicle growth was perturbed in APC2-deficient mice secondary to defective response to gonadotrophins, reduced follicular vascularity, downregulation of genes coding for steroidogenic enzymes and upregulation of Foxo1 expression, which contributed to increased apoptosis of granulosa cells in APC2-deficient follicles. At least 20\% of APC2-deficient female mice (on the background of a hypomorphic Apc allele) go on to develop WNT-driven GCT as early as 12 months. These tumours recapitulated human adult GCT histology and molecular features.

Our findings highlight the role of $\mathrm{APC} 2$ as an important regulator of WNT signalling in the ovary. Although initial studies performed in Drosophila and on cell lines to functionally-characterize APC2 demonstrated the presence of $\beta$-catenin and AXIN1 binding sites in APC2, which enable it to regulate WNT signalling [22, 23, 26, 66-68], in an in vivo mammalian setting, APC2 function is tissue specific. APC2 loss in the mouse small intestine and liver resulted in activation of WNT signalling but not in the mammary glands [33,34]. Hence, the functions of APC2 cannot be extrapolated from one mammalian system to another without direct experimentation.

The tumour suppressor role of APC2 protein in ovarian granulosa cell tumour formation has been highlighted here for the first time and the current study provides further evidence of the roles of WNT signalling activation in the pathogenesis of ovarian GCT. These findings build on previous work pointing to this role of WNT signalling in clinical data $[17,19,20,69]$, and in GEMMs $[15,17]$ but as noted above, given the tissue-specific effects of APC2 knockout, could not have been predicted a priori.

The current findings also extend our knowledge of deleterious effects of WNT signalling activation on ovarian homeostasis and fertility [10,15-17]. We have shown that reduced ovulation observed in APC2-deficient mice is not caused by defects in ovulation and terminal differentiation of granulosa cells (which happen when WNT signalling is activated in antral follicles), but rather caused by restricted follicular growth and failure to reach the pre-ovulatory stage. This phenotype is similar to previous phenotypes published when WNT signalling was activated in preantral follicles [16, 17], implying that APC2 activity is required in growing follicles as early as the pre-antral stage.

Given the constitutive nature of the $A p c 2$ null allele, both autonomous and non-autonomous mechanisms are expected to contribute to the phenotypes described. Results of the current study have clearly shown the intraovarian origin of the subfertility phenotype described in APC2-deficient mice, and that hypothalamic-pituitary regulation of ovarian function is not contributing to the subfertility phenotype. Although the subfertility is caused by increased apoptosis of granulosa cells, a contribution of endothelial cells to the phenotype was evident. Whether the same phenotype could be reproduced if APC2-deletion was targeted exclusively to granulosa cells (e.g. using Amhr2 or Cyp19a-cre) remains unknown, due to the unavailability of an $A p c 2$ conditional allele. The same applies to GCTs developing in APC2deficient mice, which - in contrast - displayed enhanced angiogenesis.

It is unlikely that WNT signalling activation is the sole driver of the reported phenotypes and cross talk between WNT signalling and other signalling pathways must also be considered. For example, unlike in early adulthood, FOXO1 expression was absent in APC2-deficient GCT, implying a need to silence FOXO1 and to stop FOXO1driven granulosa cell apoptosis as a prerequisite for tumourigenesis. It has been previously shown that knocking out Foxo1/Foxo3 leads to the development of GCT in $20 \%$ of female mice [60]. However, the cause of the 'switch' from FOXO1 being present and granulosa cell apoptosis to absent FOXO1 with granulosa cell proliferation and tumourigenesis was not identified and needs to be further characterized. The high levels of PTEN in granulosa cells of growing follicles might have contributed to increased apoptosis by inhibiting the translocation of FOXO1 outside the nucleus and thus ensuring FOXO1 activates pro-apoptotic target genes. In addition, high PTEN expression levels found in GCT of APC2-deficient ovaries might be responsible for the late development of tumourigenesis, as previously described in other models $[60,63,64]$. It is thus possible to hypothesize that, similar to previously published models, deleting Pten in granulosa cells of APC2-deficient ovaries would lead to rapid tumour development.

This study has caveats. One limitation was that the breeding data available for different genotypes of female $A p c 2$ mice $\left(A p c 2^{+/+}, A p c 2^{+/-}, A p c 2^{-/-}\right)$represented crossings to males of the corresponding genotype, rather 
than to wild type males. Effects of Apc2-gene dosage on male fertility are not yet characterized, with the caveat that male fertility might be affected in APC2-deficient male mice, and could contribute to the delayed pregnancy and reduced litter size observed in APC2deficient crosses. However, retrieval and counting of ovulated oocytes post-gonadotrophin administration confirmed that APC2-deficient female mice ovulate less and would be expected to give smaller litter size. Impairment of response to gonadotrophin is mediated by overexpression of Lhcgr, which has been recently reported to cause complete infertility in female mice, with histological analysis revealing that follicles failed to progress beyond the pre-antral stage [47]. Over-expression of Lhcgr in APC2-deficient mice most likely occurs due to canonical WNT signalling activation, as a 3.5-fold increase in Lhcgr expression levels has been reported in granulosa cells transduced with constitutively-active $\beta$ catenin, in the presence of FSH [46]. In addition, this early elevation of Lhcgr expression might have contributed to GCT development [46]. Another important caveat to this study was the small numbers of aged $A p c 2^{-/-}$ mice available for tumour development studies. This was, unfortunately, an unavoidable consequence of the reduced fertility phenotype in these animals.

\section{Conclusions}

This study advances our understanding of the role of WNT signalling in ovarian homeostasis and tumourigenesis, and of the role played by APC2 in regulating this pathway. The finding that WNT signalling activation in growing follicles impairs ovulation raises the importance of the assessment of WNT signalling activation in the setting of human female subfertility/infertility. This could provide new insights into the molecular pathogenesis of this condition, and may help in designing new treatment interventions for these patients. Furthermore, our findings extend the list of mutations which cause female subfertility or infertility in early adulthood in mice followed by development of GCT upon aging $[15,17$, $47,60]$. It remains to be determined if a similar link exists in humans and, if so, what are the molecular drivers, but APC2 must now be included on the list of candidates which should be investigated in this clinical context. Furthermore, the direct mechanistic link between WNT signalling activation, $\beta$-catenin stabilisation and GCT formation warrants further investigation.

\section{Additional files}

Additional file 1: Table S1. Primer sequences and reaction conditions used in genotyping. Table S2. Primary antibodies for

immunohistochemistry. Table S3. Taqman assays used for relative gene expression analysis. (DOCX $38 \mathrm{~kb}$ )
Additional file 2: Figure S1. APC2 is dispensable for oviduct and uterine gross morphology (.tiff). (TIF $8248 \mathrm{~kb}$ )

Additional file 3: Figure S2. APC2 is dispensable for corpora lutea (.tiff). (TIF 6547 kb)

Additional file 4: Figure S3. Constitutive loss of APC2 has no effect on fertility hormones produced by pituitary gland or on the ovulation process (.tiff). (TIF $1633 \mathrm{~kb}$ )

Additional file 5: Figure S4. Immunohistochemical localization of $\beta$ catenin protein in ovaries (.tiff). (TIF $6110 \mathrm{~kb}$ )

Additional file 6: Figure S5. Gene expression analysis of GCTs formed in a subset of APC2-deficient ovaries (.tiff). (TIF $705 \mathrm{~kb}$ )

\section{Abbreviations \\ APC: Adenomatous polyposis coli; APC2: Adenomatous polyposis coli 2; COC: Cumulus Oophorus Complex; FSH: Follicle stimulating hormone; GCT: Granulosa cell tumour; LH: Luteinizing hormone; qRT-PCR: Quantitative real-time reverse transcription PCR}

\section{Acknowledgements}

We thank Professor Hans Clevers for providing us with Apc2 $2^{-/-}$mouse, Professor Owen Sansom for critically reviewing the results, Professor Geraint Williams for training and guidance on histopathological assessment of ovaries, Elaine Taylor for assistance with mouse husbandry, Mark Bishop and Matthew Zverev for technical support and genotyping and Derek Scarborough for histologic preparation of tissues.

\section{Authors' contributions}

The research project was designed by NM, TH, MJS and ARC. NM, TH and KRR managed the mouse intercrosses. NM performed all data collection and analysis. The manuscript was drafted by NM and KRR. This manuscript is dedicated to the memory of the late Professor Alan Clarke. All other authors critically reviewed the manuscript and approved the final version submitted.

\section{Funding}

This project was funded by Egyptian Ministry of Higher Education (represented by the Egyptian Educational Bureau in London) and Cancer Research UK (ARC Programme grant C1295/A15937).

\section{Availability of data and materials}

This study contains no large data sets. The Apc2 $2^{-1-}$ mouse was provided by Professor Hans Clevers. Please contact Professor Matthew J Smalley (SmalleyMJ@Cardiff.ac.uk) for access to all other materials.

\section{Ethics approval and consent to participate}

Patient studies - not applicable, no human subjects involved. Animals studies - all experiments were carried out under the authority of UK Home Office personal and project licences (30/2737 and 30/3279) and according to ARRIVE guidelines and following local ethical review by the Cardiff University Animal Welfare Ethical Review Panel.

\section{Consent for publication}

Not applicable, no human subjects involved.

\section{Competing interests}

The authors declare that they have no competing interests. This study was previously made available via a preprint server (http://biorxiv.org/cgi/ content/short/516286v1).

\section{Author details}

${ }^{1}$ European Cancer Stem Cell Research Institute, Cardiff University School of Biosciences, Hadyn Ellis Building, Maindy, Road, Cardiff CF24 4HQ, UK ${ }^{2}$ Hormones Evaluation Department, National Organization for Drug Control and Research (NODCAR), Giza, Egypt. ${ }^{3}$ Present address: CRUK Beatson Institute, Switchback road, Bearsden, Glasgow G61 1BD, UK. 
Received: 1 February 2019 Accepted: 24 June 2019

\section{Published online: 10 July 2019}

\section{References}

1. Clevers H, Nusse R. Wnt/ $\beta$-catenin signaling and disease. Cell. 2012;149(6): 1192-205.

2. Biason-Lauber A, Chaboissier MC. Ovarian development and disease: the known and the unexpected. Semin Cell Dev Biol. 2015;45:59-67.

3. Chassot A-A, Ranc F, Gregoire EP, Roepers-Gajadien HL, Taketo MM, Camerino G, De Rooij DG, Schedl A, Chaboissier M-C. Activation of $\beta$ catenin signaling by Rspo1 controls differentiation of the mammalian ovary. Hum Mol Genet. 2008;17(9):1264-77.

4. Tomizuka K, Horikoshi K, Kitada R, Sugawara Y, Iba Y, Kojima A, Yoshitome A, Yamawaki K, Amagai M, Inoue A, et al. R-spondin 1 plays an essential role in ovarian development through positively regulating Wnt-4 signaling. Hum Mol Genet. 2008;17(9):1278-91.

5. Ottolenghi C, Pelosi E, Tran J, Colombino M, Douglass E, Nedorezov T, Cao A, Forabosco A, Schlessinger D. Loss of Wnt4 and Foxl2 leads to female-tomale sex reversal extending to germ cells. Hum Mol Genet. 2007;16(23): 2795-804.

6. Maatouk DM, DiNapoli L, Alvers A, Parker KL, Taketo MM, Capel B. Stabilization of beta-catenin in XY gonads causes male-to-female sexreversal. Hum Mol Genet. 2008;17(19):2949-55.

7. Jameson SA, Lin YT, Capel B. Testis development requires the repression of Wnt4 by Fgf signaling. Dev Biol. 2012;370(1):24-32.

8. Domenice S, Correa RV, Costa EM, Nishi MY, Vilain E, Arnhold IJ, Mendonca BB. Mutations in the SRY, DAX1, SF1 and WNT4 genes in Brazilian sexreversed patients. Braz J Med Biol Res. 2004;37(1):145-50.

9. Tomaselli S, Megiorni F, De Bernardo C, Felici A, Marrocco G, Maggiulli G, Grammatico B, Remotti D, Saccucci $P$, Valentini $F$, et al. Syndromic true hermaphroditism due to an R-spondin1 (RSPO1) homozygous mutation. Hum Mutat. 2008;29(2):220-6.

10. Fan H-Y, O'Connor A, Shitanaka M, Shimada M, Liu Z, Richards JS. $\beta$-Catenin (CTNNB1) promotes Preovulatory follicular development but represses LHmediated ovulation and Luteinization. Mol Endocrinol. 2010;24(8):1529-42.

11. Hernandez Gifford JA, Hunzicker-Dunn ME, Nilson JH. Conditional deletion of Beta-catenin mediated by Amhr2cre in mice causes female infertility. Biol Reprod. 2009;80(6):1282-92.

12. Boyer A, Lapointe É, Zheng X, Cowan RG, Li H, Quirk SM, DeMayo FJ, Richards JS, Boerboom D. WNT4 is required for normal ovarian follicle development and female fertility. FASEB J. 2010;24(8):3010-25.

13. Hsieh M, Boerboom D, Shimada M, Lo Y, Parlow AF, Luhmann UF, Berger W, Richards JS. Mice null for Frizzled4 (Fzd4-/-) are infertile and exhibit impaired corpora lutea formation and function. Biol Reprod. 2005;73(6): $1135-46$.

14. Lapointe E, Boyer A, Rico C, Paquet M, Franco HL, Gossen J, DeMayo FJ, Richards JS, Boerboom D. FZD1 regulates cumulus expansion genes and is required for Normal female fertility in mice. Biol Reprod. 2012;87(5):104.

15. De Cian MC, Pauper E, Bandiera R, Vidal VP, Sacco S, Gregoire EP, Chassot

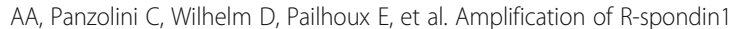
signaling induces granulosa cell fate defects and cancers in mouse adult ovary. Oncogene. 2016;36(2):208-18.

16. Abedini A, Zamberlam G, Lapointe E, Tourigny C, Boyer A, Paquet M, Hayashi K, Honda H, Kikuchi A, Price C, et al. WNT5a is required for normal ovarian follicle development and antagonizes gonadotropin responsiveness in granulosa cells by suppressing canonical WNT signaling. FASEB J. 2016; 30(4):1534-47.

17. Boerboom D, Paquet M, Hsieh M, Liu J, Jamin SP, Behringer RR, Sirois J, Taketo MM, Richards JS. Misregulated Wnt/beta-catenin signaling leads to ovarian granulosa cell tumor development. Cancer Res. 2005;65(20):9206-15.

18. Colombo N, Peiretti M, Castiglione M. Non-epithelial ovarian cancer: ESMO clinical recommendations for diagnosis, treatment and follow-up. Ann Oncol. 2009;20(Suppl 4):24-6.

19. Kilonzo BM, Neff T, Samuelson MI, Goodheart MJ. Wnt signaling in granulosa cell tumors of the ovary. Proc Obstet Gynecol. 2015;4(3):1-1.

20. Stewart CJ, Doherty D, Guppy R, Louwen K, Leung YC. $\beta$-Catenin and Ecadherin expression in stage I adult-type granulosa cell tumour of the ovary: correlation with tumour morphology and clinical outcome. Histopathology. 2013;62(2):257-66.

21. Clevers H. Wnt/beta-catenin signaling in development and disease. Cell. 2006;127(3):469-80.
22. van Es JH, Kirkpatrick C, van de Wetering M, Molenaar M, Miles A, Kuipers J, Destrée $\mathrm{O}$, Peifer $\mathrm{M}$, Clevers $\mathrm{H}$. Identification of APC2, a homologue of the adenomatous polyposis coli tumour suppressor. Curr Biol. 1999;9(2):105-8.

23. Roberts DM, Pronobis MI, Poulton JS, Kane EG, Peifer M. Regulation of Wnt signaling by the tumor suppressor adenomatous polyposis coli does not require the ability to enter the nucleus or a particular cytoplasmic localization. Mol Biol Cell. 2012;23(11):2041-56.

24. Schneikert J, Vijaya Chandra SH, Ruppert JG, Ray S, Wenzel EM, Behrens J. Functional comparison of human adenomatous polyposis coli (APC) and APClike in targeting beta-catenin for degradation. PLoS One. 2013;8(7):e68072.

25. Sansom OJ, Reed KR, Hayes AJ, Ireland H, Brinkmann H, Newton IP, Batlle E, Simon-Assmann P, Clevers H, Nathke IS, et al. Loss of Apc in vivo immediately perturbs Wnt signaling, differentiation, and migration. Genes Dev. 2004;18(12):1385-90.

26. Hamada F, Murata Y, Nishida A, Fujita F, Tomoyasu Y, Nakamura M, Toyoshima K, Tabata T, Ueno N, Akiyama T: Identification and characterization of E-APC, a novel Drosophila homologue of the tumour suppressor APC. Genes to cells : devoted to molecular \& cellular mechanisms 1999, 4(8):465-474.

27. McCartney BM, Dierick HA, Kirkpatrick C, Moline MM, Baas A, Peifer M, Bejsovec A. Drosophila APC2 is a cytoskeletally-associated protein that regulates wingless signaling in the embryonic epidermis. J Cell Biol. 1999; 146(6):1303-18

28. Jarrett CR, Blancato J, Cao T, Bressette DS, Cepeda M, Young PE, King CR, Byers SW. Human APC2 localization and allelic imbalance. Cancer Res. 2001; 61(21):7978-84

29. Shintani T, Ihara M, Tani S, Sakuraba J, Sakuta H, Noda M. APC2 plays an essential role in axonal projections through the regulation of microtubule stability. J Neurosci. 2009;29(37):11628-40.

30. Shintani T, Takeuchi Y, Fujikawa A, Noda M. Directional neuronal migration is impaired in mice lacking adenomatous polyposis coli 2. J Neurosci. 2012; 32(19):6468-84.

31. Nakagawa H, Koyama K, Murata Y, Morito M, Akiyama T, Nakamura Y. EB3, a novel member of the EB1 family preferentially expressed in the central nervous system, binds to a CNS-specific APC homologue. Oncogene. 2000; 19(2):210-6

32. McCartney BM, McEwen DG, Grevengoed E, Maddox P, Bejsovec A, Peifer M Drosophila APC2 and Armadillo participate in tethering mitotic spindles to cortical actin. Nat Cell Biol. 2001;3(10):933-8.

33. Daly $\mathrm{C}$. The roles of the Apc proteins in homeostasis and tumourigenesis. Cardiff: Cardiff University; 2013.

34. Daly CS, Shaw P, Ordonez LD, Williams GT, Quist J, Grigoriadis A, Van Es JH, Clevers $\mathrm{H}$, Clarke AR, Reed KR. Functional redundancy between Apc and Apc2 regulates tissue homeostasis and prevents tumorigenesis in murine mammary epithelium. Oncogene. 2016;36(13):1793-803.

35. Perets R, Wyant GA, Muto KW, Bijron JG, Poole BB, Chin KT, Chen JYH, Ohman AW, Stepule CD, Kwak S. Transformation of the fallopian tube secretory epithelium leads to high-grade serous ovarian Cancer in Brca; Tp53; Pten Models. Cancer Cell. 2013;24(6):751-65.

36. van der Meer M, Baumans V, Hofhuis FM, Olivier B, van Zutphen BF. Consequences of gene targeting procedures for behavioural responses and morphological development of newborn mice. Transgenic Res. 2001;10(5):399-408.

37. Buchert M, Athineos D, Abud HE, Burke ZD, Faux MC, Samuel MS, Jarnicki AG, Winbanks CE, Newton IP, Meniel VS, et al. Genetic dissection of differential signaling threshold requirements for the Wnt/beta-catenin pathway in vivo. PLoS Genet. 2010;6(1):e1000816.

38. Shibata H, Toyama K, Shioya H, Ito M, Hirota M, Hasegawa S, Matsumoto H, Takano H, Akiyama T, Toyoshima K, et al. Rapid colorectal adenoma formation initiated by conditional targeting of the Apc gene. Science. 1997;278(5335):120-3.

39. Luo C, Zuñiga J, Edison E, Palla S, Dong W, Parker-Thornburg J. Superovulation strategies for 6 commonly used mouse strains. J Am Assoc Lab Anim Sci. 2011;50(4):471-8.

40. Zudova D, Wyrobek AJ, Bishop J, Marchetti F. Impaired fertility in T-stock female mice after superovulation. Reproduction. 2004;128(5):573-81.

41. Kiyosu C, Tsuji T, Yamada K, Kajita S, Kunieda T. NPPC/NPR2 signaling is essential for oocyte meiotic arrest and cumulus oophorus formation during follicular development in the mouse ovary. Reproduction. 2012; 144(2):187-93.

42. Brown C, LaRocca J, Pietruska J, Ota M, Anderson L, Smith SD, Weston P, Rasoulpour T, Hixon ML. Subfertility caused by altered follicular development and oocyte growth in female mice lacking PKB alpha/Akt1. Biol Reprod. 2010;82(2):246-56. 
43. Balla A, Danilovich N, Yang Y, Sairam MR. Dynamics of ovarian development in the FORKO immature mouse: structural and functional implications for ovarian reserve. Biol Reprod. 2003;69(4):1281-93.

44. Visser JA, Durlinger AL, Peters IJ, van den Heuvel ER, Rose UM, Kramer P, de Jong FH, Themmen AP. Increased oocyte degeneration and follicular atresia during the estrous cycle in anti-Mullerian hormone null mice. Endocrinology. 2007;148(5):2301-8.

45. Cumming G, Fidler F, Vaux DL. Error bars in experimental biology. J Cell Biol. 2007;177(1):7-11

46. Law NC, Weck J, Kyriss B, Nilson JH, Hunzicker-Dunn M. Lhcgr expression in granulosa cells: roles for PKA-phosphorylated $\beta$-catenin, TCF3, and FOXO1. Mol Endocrinol. 2013;27(8):1295-310.

47. Hai L, McGee SR, Rabideau AC, Paquet M, Narayan P. Infertility in female mice with a gain-of-function mutation in the luteinizing hormone receptor is due to irregular estrous Cyclicity, anovulation, hormonal alterations, and polycystic ovaries. Biol Reprod. 2015;93(1):16.

48. Shen M, Lin F, Zhang J, Tang Y, Chen WK, Liu H. Involvement of the upregulated FoxO1 expression in follicular granulosa cell apoptosis induced by oxidative stress. J Biol Chem. 2012;287(31):25727-40.

49. Kim JH, Yoon S, Park M, Park HO, Ko JJ, Lee K, Bae J. Differential apoptotic activities of wild-type FOXL2 and the adult-type granulosa cell tumorassociated mutant FOXL2 (C134W). Oncogene. 2011;30(14):1653-63.

50. Matsuda F, Inoue N, Maeda A, Cheng Y, Sai T, Gonda H, Goto Y, Sakamaki K, Manabe N. Expression and function of apoptosis initiator FOXO3 in granulosa cells during follicular atresia in pig ovaries. J Reprod Dev. 2011; 57(1):151-8.

51. Stapp AD, Gomez BI, Gifford CA, Hallford DM, Hernandez Gifford JA. Canonical WNT signaling inhibits follicle stimulating hormone mediated steroidogenesis in primary cultures of rat granulosa cells. PLoS One. 2014; 9(1):e86432.

52. Li L, Ji SY, Yang JL, Li XX, Zhang J, Zhang Y, Hu ZY, Liu YX. Wnt/beta-catenin signaling regulates follicular development by modulating the expression of Foxo3a signaling components. Mol Cell Endocrinol. 2014;382(2):915-25.

53. Tzivion $\mathrm{G}$, Dobson M, Ramakrishnan $\mathrm{G}$. FoxO transcription factors; regulation by AKT and 14-3-3 proteins. Biochim Biophys Acta (BBA) - Mol Cell Res. 2011;1813(11):1938-45.

54. Tanwar PS, Kaneko-Tarui T, Lee H-J, Zhang L, Teixeira JM. PTEN loss and HOXA10 expression are associated with ovarian endometrioid adenocarcinoma differentiation and progression. Carcinogenesis. 2013;34(4): 893-901.

55. Taddei A, Giampietro C, Conti A, Orsenigo F, Breviario F, Pirazzoli V, Potente M, Daly C, Dimmeler S, Dejana E. Endothelial adherens junctions control tight junctions by VE-cadherin-mediated upregulation of claudin-5. Nat Cell Biol. 2008;10(8):923-34.

56. Robinson RS, Woad KJ, Hammond AJ, Laird M, Hunter MG, Mann GE. Angiogenesis and vascular function in the ovary. Reproduction. 2009;138(6):869-81.

57. Tanwar PS, Zhang L, Kaneko-Tarui T, Curley MD, Taketo MM, Rani P, Roberts DJ, Teixeira JM. Mammalian target of rapamycin is a therapeutic target for murine ovarian endometrioid adenocarcinomas with dysregulated Wnt/ beta-catenin and PTEN. PLoS One. 2011;6(6):e20715.

58. van der Horst PH, van der Zee M, Heijmans-Antonissen C, Jia Y, DeMayo FJ, Lydon JP, van Deurzen CH, Ewing PC, Burger CW, Blok LJ. A mouse model for endometrioid ovarian cancer arising from the distal oviduct. Int I Cancer. 2014;135(5):1028-37.

59. Gao Y, Vincent DF, Davis AJ, Sansom OJ, Bartholin L, Li Q. Constitutively active transforming growth factor beta receptor 1 in the mouse ovary promotes tumorigenesis. Oncotarget. 2016;7(27):40904-18.

60. Liu Z, Ren YA, Pangas SA, Adams J, Zhou W, Castrillon DH, Wilhelm D, Richards JS. FOXO1/3 and PTEN depletion in granulosa cells promotes ovarian granulosa cell tumor development. Mol Endocrinol. 2015;29(7): 1006-24.

61. D'Angelo E, Mozos A, Nakayama D, Espinosa I, Catasus L, Munoz J, Prat J. Prognostic significance of FOXL2 mutation and mRNA expression in adult and juvenile granulosa cell tumors of the ovary. Mod Pathol. 2011;24(10): 1360-7.

62. Kaspar HG, Crum CP. The utility of immunohistochemistry in the differential diagnosis of gynecologic disorders. Arch Pathol Lab Med. 2015;139(1):39-54.

63. Lague MN, Paquet M, Fan HY, Kaartinen MJ, Chu S, Jamin SP, Behringer RR, Fuller PJ, Mitchell A, Dore M, et al. Synergistic effects of Pten loss and WNT/ CTNNB1 signaling pathway activation in ovarian granulosa cell tumor development and progression. Carcinogenesis. 2008;29(11):2062-72.
64. Richards JS, Fan HY, Liu Z, Tsoi M, Lague MN, Boyer A, Boerboom D. Either Kras activation or Pten loss similarly enhance the dominant-stable CTNNB1induced genetic program to promote granulosa cell tumor development in the ovary and testis. Oncogene. 2012;31(12):1504-20.

65. Jefferies MT, Cox AC, Shorning BY, Meniel V, Griffiths D, Kynaston HG, Smalley MJ, Clarke AR. PTEN loss and activation of K-RAS and beta-catenin cooperate to accelerate prostate tumourigenesis. J Pathol. 2017;243(4):442-56.

66. Ahmed $Y$, Nouri A, Wieschaus E. Drosophila Apc1 and Apc2 regulate wingless transduction throughout development. Development. 2002;129(7): 1751-62.

67. Akong K, Grevengoed EE, Price MH, McCartney BM, Hayden MA, DeNofrio JC, Peifer M. Drosophila APC2 and APC1 play overlapping roles in wingless signaling in the embryo and imaginal discs. Dev Biol. 2002;250(1):91-100.

68. McCartney BM, Price MH, Webb RL, Hayden MA, Holot LM, Zhou M, Bejsovec A, Peifer M. Testing hypotheses for the functions of APC family proteins using null and truncation alleles in Drosophila. Development. 2006; 133(12):2407-18.

69. Xu Y, Li X, Wang H, Xie P, Yan X, Bai Y, Zhang T. Hypermethylation of $\mathrm{CDH} 13, \mathrm{DKK} 3$ and FOXL2 promoters and the expression of EZH2 in ovary granulosa cell tumors. Mol Med Rep. 2016;14(3):2739-45.

\section{Publisher's Note}

Springer Nature remains neutral with regard to jurisdictional claims in published maps and institutional affiliations.

\section{Ready to submit your research? Choose BMC and benefit from:}

- fast, convenient online submission

- thorough peer review by experienced researchers in your field

- rapid publication on acceptance

- support for research data, including large and complex data types

- gold Open Access which fosters wider collaboration and increased citations

- maximum visibility for your research: over $100 \mathrm{M}$ website views per year

At BMC, research is always in progress.

Learn more biomedcentral.com/submissions 